\title{
PERAN KEPALA SEKOLAH DALAM PENINGKATAN MUTU PENDIDIKAN ISLAM
}

FAUZI SAYUTI

(DOSEN STAI AL-KHAIRAT PAMEKASAN)

Email:fauzi_sayuti@gmail.com

\begin{abstract}
The school principal has a very important role in improving the quality of the institution. This is because; in the hands of a leader who is a 'master' in his institution will occur changes to the quality standards expected. The exact roles and appropriate functions must be done by a school principal to achieve the goal. A school principal is emphasized to understand what role should be done, whether as an educator, manager, administrator, supervisor, leader, innovator, or motivator. By understanding and doing the school principal well so the school principal will be able to lead the institution well.

In addition, the school principal must have spirit of struggle as agent of change in improving the quality of education to the defined quality standard. This can be done with the steps include: the formulation of the vision, mission, goals and objectives of institution, decision-making, SWOT analysis, programs plan to improve the quality, transparency, participation of school and society, independence and accountability, and changes to the quality standard.
\end{abstract}

\section{Abstrak}

Kepala sekolah mempunyai peran yang sangat penting untuk meningkatkan kualitas lembaga yang dipimpinnya. Hal ini dikarenakan, di tangan pemimpin yang merupakan 'nahkoda' dalam lembaga yang dipimpinnya akan terjadi perubahan-perubahan menuju standar mutu yang diharapkan. Peran yang tepat dan fungsi yang sesuai harus dijalankan oleh seorang kepala sekolah untuk mencapai tujuan tersebut. Seorang kepala sekolah dituntut untuk memahami peran apa yang harus dijalankannya, apakah sebagai educator, manager, administrator, supervisor, leader, innovator, atau motivator. Dengan mengetahui dan menjalankan dengan benar peran kepemimpinan tersebut, maka kepala sekolah akan mampu memimpin lembaga yang dipimpinnya dengan baik.

Selain itu, kepala sekolah harus mempunyai ghirrah perjuangan sebagai agent of change dalam meningkatkan kualitas pendidikan yang dipimpinnya menuju standar mutu yang ditetapkan. Hal tersebut dapat dilakukan dengan langkah antara lain: perumusan visi, misi, tujuan dan sasaran lembaga, pengambilan keputusan, analisis SWOT, penyusunan program peningkatan mutu, keterbukaan, partisipasi warga sekolah dan 
masyarakat, kemandirian dan akuntabilitas, dan perubahan menuju sadar mutu.

Kata Kunci: Kepala Sekolah, Mutu, Pendidikan Islam

\section{Pendahuluan}

Betapa pentingnya peran kepala sekolah dalam menjalankan roda kepemimpinannya. Hal ini sinergi dengan kemajuan yang akan diperoleh oleh sekolah apabila dipimpin oleh pemimpin yang tepat. Fakta membuktikan bahwa di tangan seorang pemimpin yang hebat, sekolah biasa bisa menjadi sekolah berkualitas dalam waktu yang singkat. Pemimpin yang berkualitas mampu menciptakan terobosan-terobosan atau inovasi sehingga sekolah yang dipimpinnya terus berkembang menuju puncak tujuannya. Seorang pemimpin yang hebat juga mampu memompa semangat kerja orang yang dipimpinnya, sehingga tiada tekanan tetapi bekerja dengan suka rela sehingga bisa diperoleh hasil yang maksimal.

Dalam dunia pendidikan kepala sekolah dituntut untuk menjadi pemimpin ideal agar lembaga yang dipimpinnya bisa maju, menerapkan manajemen berkualitas, menghasilkan output berupa siswa yang berkualitas pula. Hal tersebut bisa diwujudkan dengan kepala sekolah yang memahami peran dan tugasnya. Lembaga-lembaga pendidikan Islam diharapkan mempunyai para kepala sekolah yang bisa memahami peran dan tugasnya dengan baik. Dengan harapan agar sekolah-sekolah Islam bisa mencetak generasi penerus bangsa yang berkualitas pada nantinya.

\section{Kepala Sekolah sebagai Pemimpin Pendidikan}

Makna pemimpin pendidikan diterangkan sebagai orang yang bertanggung jawab dalam kepemimpinan pendidikan. Kepemimpinan pendidikan dalam pengertian ini adalah proses mempengaruhi semua personel yang mendukung pelaksanaan aktivitas pembelajaran dalam rangka mencapai tujuan pendidikan di sekolah. Para pemimpin pendidikan harus memiliki komitmen terhadap perbaikan mutu dalam fungsi utamanya. Oleh karena itu, fungsi dari kepemimpinan pendidikan haruslah tertuju pada kualitas pembelajaran serta semua staff yang mendukungnya. Keberadaan anggota atau staff juga penting dalam organisasi. Dalam hal ini adalah di sekolah ${ }^{1}$.

Kepala sekolah adalah orang yang berada di garis terdepan yang mengkoordinasikan upaya meningkatkan pembelajaran yang bermutu. Kepala sekolah diangkat untuk menduduki jabatan yang bertanggung jawab mengkoordinasikan upaya bersama mencapai tujuan pendidikan pada level

1 Syafaruddin, Manajemen Mutu Terpadu dalam Pendidikan, Konsep, Strategi, dan Aplikasi, (Jakarta: PT. Grasindo, 2002), . 
sekolah masing-masing. Dalam praktiknya, di Indonesia kepala sekolah adalah guru senior yang dipandang memiliki kualifikasi menduduki jabatan tersebut. ${ }^{2}$

Educational administrators who manage elementary, middle, and secondary schools are called Principals. They set academic tone and hire, evaluate, and help to improve skills of teachers and other staff. Principals cover with staff to advice, explain, or answer procedural questions. They visit classrooms, observe teaching methods, review instructional objectives, and examine learning materials. ${ }^{3}$

Administrator yang mengatur sekolah dasar, menengah, dan lanjutan disebut kepala sekolah. Ia mengatur irama pendidikan, penggajian, evaluasi, dan meningkatkan keahlian guru dan staf lain. Ia bertanggungjawab untuk memberikan nasehat, penjelasan, dan pertanyaan-pertanyaan prosedural juga mengunjungi kelas-kelas, meneliti metode mengajar, mereview tujuan pembelajaran, dan menilai materi pembelajaran.

Educational leadership is defined and theorized in multiple ways to encapsulate the concepts, practices and perceptions in diverse contexts. However, theories and practices related to education in general and educational leadership in particular are predominantly ethnocentric, embedded in Western philosophy and values. ${ }^{4}$

Kepemimpinan pendidikan didefinisikan dan diartikan dengan berbagai cara untuk menunjukkan konsep, anggapan, dan praktiknya dalam berbagai macam konteks. Bagaimanapun juga, teori dan praktik pendidikan secara umum dan kepemimpinan pendidikan secara khusus hal yang etnosentrik baik pada filosofi barat maupun nilainya.

Dalam konsep dan penerapannya berbeda-beda di masyarakat dan budaya, pemaknaan kepemimpinan yang berbeda tersebut mencerminkan sudut pandang dan asumsi secara filosofis dan teori dan pengetahuan yang mereka punya. Perbedaan ini dikarenakan bukan hanya karena konsep dan filosofi yang bervariasi, tetapi juga karena kepemipinan berasal dari kekuasaan dan pengaruh sumber daya baik secara formal maupun nonformal, baik segi posisi orang, pengetahuan, dan kebijaksanaan.

Aan Komariah mengungkakan bahwa kepemimpinan pendidikan yang diperlukan saat ini adalah yang didasarkan pada jati diri bangsa yang hakiki yang bersumber dari nilai-nilai budaya dan agama serta mampu mengantisipasi perubahan yang terjadi dalam dunia pendidikan khususnya dan umumnya atas kemajuan-kemajuan yang diraih di luar sistem sekolah. Dengan demikian, maka kepala sekolah hendaknya memiliki visi kelembagaan kemampuan konsepsional yang jelas, serta memiliki keterampilan dan seni dalam hubungan antara manusia, penguasaan aspek aspek teknis dan substantif, memiliki semangat untuk maju

2 Agus Dharma, “Dicari Kepala Sekolah yang Kompeten: Standard Kompetensi Kepala Sekolah," http://artikel.us/adharma.html, diakses pada tanggal 11 maret 2012.

${ }^{3}$ Kathleen Cushman, "The Essential School Principal: A Changing Role In A Changing School," http://www.essentialschool.org/cs/resource/viw/ces res/102, diakses pada tanggal 12 Maret 2012.

4 Saeeda Jasaah, "Re-thinking Educational Leadership:Exploring The Impact of Cultural and Belief Systems," http://www.tandfonline.com/page/terms-andconditions. dx.doi.org/10.1080/13603120903244879), diakses 2010. 
serta semangat mengabdi dan karakter yang diterima oleh masyarkat lingkungannya. Kepala sekolah harus luwes dalam bersikap kepada para staf agar tidak terjadi kekakuan dalam hubungan dan komunikasi. Seorang pemimpin yang baik adalah seorang ahli komunikasi yang baik. ${ }^{5}$

Dari beberapa uraian tersebut dapat disimpulkan bahwa agar tercipta kondisi yang memungkinkan sehingga siswa dapat mencapai tujuan pendidikan secara efektif dan efisien maka diperlukan seorang pemimpin yakni kepala sekolah. Kepala sekolah harus mau dan mampu menjalankan fungsi-fungsi manajemen atau pengelolaan yang meliputi perencanaan, pengorganisasian, pengendalian dan inovasi dalam berbagai bidang administrasi seperti administrasi kesiswaan, kepegawaian, program pengajaran, kurikulum, sarana dan prasarana, keuangan, tata usaha, hubungan sekolah dan masyarakat dan administrasi lingkungan sekolah.

\section{Tugas dan Peran Kepala Sekolah dalam Kepemimpinan}

\section{a. Kepala Sekolah sebagai Educator}

Ada beberapa hal yang harus dilakukan kepala sekolah dalam perannya sebagai educator yaitu:

1) Promoting quality instruction.

2) Supervising and Evaluating Instruction.

3) Allocating and Protecting Instructional Time.

4) Coordinating the Curriculum.

5) Promoting Content Coverage.

6) Monitoring Students Progress. ${ }^{6}$

Peran kepala sekolah sebagai pendidik adalah: pertama selalu konsisten dan mengkoordinasikan program-program pengajaran dan menemukan metode pengajaran yang baik; kedua selalu konsisten dan mengkoordinasikan program-program pengajaran dan menemukan metode pengajaran yang baik; ketiga menyediakan guru yang konsisten terhadap waktu pengajaran dan menjamin bahwa guru memahami materi yang akan diajarkan; keempat menterjemahkan kurikulum kedalam kurikulum yang bermakna. Menyesuaikan tujuan pengajaran dengan materi kurikulum yang bersifat fertikal ke horizontal; kelima menjamin bahwa isi dari materi khusus dipakai dikelas dan juga diberikan diluar kelas dengan mengembangkan antara pekerjaan rumah yang tidak memaksa; keenam menggunakan criteria dan standarsisasi dengan menggunakan referensi test untuk menentukan masalahmasalah siswa dan mengevaluasi perkembangannya, seperti halnya menggunakan hasil test untuk memodifikasi target sekolah.

Sebagai pendidik kepala sekolah harus mampu menanamkan, memajukan, dan meningkatkan paling tidak empat nilai:

1) Mental, hal yang berkaitan denagn sikap batin dan watak manusia.

${ }^{5}$ Aan Komariah \& Cepi Triatna, University Leadership, Menuju Sekolah Efektif, (Jakarta: PT. Bumi Aksara, 2006), .

${ }^{6}$ F. C Lunenburg, Educational Administration, (Belswart: Wordsworth, 2004), . 
2) Moral, hal yang berkaitan dengan ajaran baik buruk mengenai perbuatan, sikap dan kewajiban yang diartikan sebagai akhlak, budi pekerti, dan kesusilaan.

3) Fisik, hal yang berkaitan dengan kondisi jasmani atau badan, kesehatan, dan penampilan manusia secara lahiriyah.

4) Artistik, hal yang berkaitan kepekaan manusia terhadap seni dan keindahan.7

Dengan bekal empat hal tersebut kepala sekolah mampu membawa bahtera sekolah yang dipimpinnya menjadi lebih baik dan maju. Bagaimanapun juga kepala sekolah harus bisa menjalankan perannya sebagai pendidik yang bisa memberikan suri tauladan kepada masyarakat sekolah yang dipimpinnya termasuk siswa, karena siswa akan meniru contoh yang diberikan kepala sekolah sebagai bekal kehidupannya di masa depan. Menjadi seorang pendidik yang baik juga bisa diterapkan dengan cara menumbuhkan dan menciptakan budaya-budaya positif yang nanti menjadi kebiasaan bagi masyarakat sekolah.

\section{b. Kepala Sekolah sebagai Manager}

Karena kepala sekolah dituntut memiliki kemampuan untuk berperilaku sebagaimana layaknya seorang manajer dalam suatu organisasi sekolah, maka pemahaman tentang apa itu manajer dan apa yang harus dilaksanakan kepala sekolah selaku manajer harus diketahui terlebih dahulu. Seorang manajer berperan untuk mengorganisasi sumber daya yang tersedia agar mencapai sasaran tertentu. ${ }^{8}$

Sehubungan dengan ungkapan tersebut, kepala sekolah sebagai pengendali roda organisasi di sekolah mampu merencanakan semua kegiatan untuk jangka pendek, menengah, dan jangka panjang dengan tetap mengacu pada visi, misi, tujuan dan sasaran sekolah yang akan dicapai dengan sejalan payungan pembangunan daerah dimana sekolah itu berada. Selaku manajer, dalam menyusun semua strategi pembangunan di sekolah kepala sekolah tidak menyangkal kondisi keperluan yang berkembang di dalam lingkungan sekolah maupun yang ada di luar lingkungan sekolah. Strategi tersebut ditinjau dari bahan pertimbangan yang cermat dan dengan prinsip kehati-hatian untuk mengambil keputusan serta kebijakan seperti masalah ekonomi, sosial, budaya, sumber daya manusia, sumber daya alam, sumber daya keuangan, politik serta sarana prasarana yang dimiliki oleh sekolah juga masyarakat. Pengorganisasian semua program kerja harus dimobilisasi secara profesional. Pihak menajer memutuskan pekerjaan mana yang harus diisi serta pembagian tugastugas dan tanggungjawab yang berkaitan dengan masing-masing pekerjaan.

Kepala sekolah sebagai manajer dalam mengelola tenaga kependidikan, salah satu tugas yang harus dilakukan kepala sekolah adalah melaksanakan

7 Wahjosumidjo, Kepemimpinan Kepala Sekolah; Tinjauan Teoritis dan Permasalahannya, (Jakarta: PT. Grapindo Persada, 2010), .

8 Winardi, Manajemen Sekolah dan Kepemimpinan Mandiri Kepala Sekolah, Edisi 2, (Bandung: Sarana Punca Karya Nusa, 2000), . 
kegiatan pemeliharaan dan pengembangan profesi para guru. Dalam hal ini, kepala sekolah seyogyanya dapat memfasiltasi dan memberikan kesempatan yang luas kepada para guru untuk dapat melaksanakan kegiatan pengembangan profesi melalui berbagai kegiatan pendidikan dan pelatihan, baik yang dilaksanakan di sekolah, -seperti : MGMP/MGP tingkat sekolah, in house training, diskusi profesional dan sebagainya-, atau melalui kegiatan pendidikan dan pelatihan di luar sekolah, seperti : kesempatan melanjutkan pendidikan atau mengikuti berbagai kegiatan pelatihan yang diselenggarakan pihak lain. ${ }^{9}$

Sehubungan dengan peran tersebut, dalam penempatan tenaga kerja atau tenaga kependidikan dan tenaga non kependidikan manajer perlu memperhatikan kompetensi yang dimiliki. Jangan sampai terjadi tindakan korupsi, kolusi, dan nepotisme pada saat perekrutan staf, pengisian atau pengadaan tenaga pengelola sekolah dan harus disesuaikan dengan kebutuhan dan kualifikasi pekerjaan yang diperlukan. Sebagai manajer, kepala sekolah bertugas mengawasi pelaksanan tugas-tugas aparat sekolah secara berkesinambungan. Sedangakan sebagai pemimpin pengajaran kepala sekolah bertangungjawab dalam pelaksanaan peningkatan mutu program pengajaran.

Dari uraian diatas dapat disimpulkan bahwa kepala sekolah sebagai menajer haruslah mempunyai kompetensi untuk mengelola dan mengendalikan semua program maupun rencana pengembangan sekolah hingga mencapai harapan yang didambakan bersama dengan warga sekolah.

\section{c. Kepala Sekolah sebagai Administrator}

Administrasi dapat didefinikan sebagai proses kerjasama antara dua orang atau lebih untuk mencapai tujuan tertentu secara produktif. Istilah produktif mengandung makna efisien dan efektif. Efisiensi merujuk pada proses kerja sedangkan efektifitas merujuk kepada hasil. Administrasi pendidikan dapat didefinisikan sebagai proses kerja sama sumber daya manusia kependidikan dengan memanfaatkan potensi yang ada dan yang sesuai (manusia, material, uang, teknologi, dan situasi) untuk mencapai tujuan pendidikan secara efektif dan efisien. ${ }^{10}$

Keterampilan yang harus dimiliki oleh administrator yang efektif adalah keterampilan teknis, keterampilan hubungan manusiawi, dan keterampilan konseptual yang penjelasannya adalah:

1) Keterampilan teknis: adalah keterampilan yang meliputi keterampilan menyusun laporan pertanggungjawaban, keterampilan menyusun program tertulis, keterampilan membuat data statistik sekolah, keterampilan membuat keputusan dan merealisasikannya, keterampilan mengetik, keterampilan menata ruang, keterampilan membuat surat.

\footnotetext{
9 Akhmad Sudrajat, “Kepemimpinan Pendidikan'” (http://.wordpress.com/ kompetensiguru-dan-peran-kepala-sekolah-2/), diakses pada tanggal 20 Mei 2014.

10 Aan Komariah \& Cepi Triatna, University Leadership, Menuju Sekolah Efektif, (Jakarta: PT. Bumi Aksara, 2006), .
} 
2) keterampilan hubungan manusiawi: keterampilan menempatkan diri dalam kelompok, keterampilan menciptakan kepuasan pada diri bawahan, sikap terbuka terhadap kelompok kerja, kemampuan mengambil hati melalui keramahtamahan, penghargaan terhadap nilai-nilai etis, pemerataan tugas dan tanggungjawab, i'tikad baik, adil, menghormati, dan menghargai orang lain.

3) keterampilan konseptual adalah kecakapan untuk memformulasikan pikiran, memahami teori-teori, melakukan aplikasi, melihat kecenderungan berdasarkan kemampuan teoritis dan yang dibutuhkan di dalam dunia kerja. Kepala sekolah atau pengelola pendidikan dituntuk dapat memahami konsep dan teori yang erat hubungannya dengan pekerjaan. ${ }^{11}$

\section{d. Kepala Sekolah sebagai Supervisor}

Selain bertugas mengajar, kepala sekolah juga ditugaskan untuk memberikan perhatian yang seimbang dengan tugasnya merencanakan, melaksanakan, hingga mengevaluasi kegiatan supervisi pendidikan di sekolah. Adapun yang dimaksud dengan supervisi sebagaimana dikemukakan oleh Sergiovani :

Supervision is a process designed to help teacher and supervisor team more about

their practice; to better able to use their knowledge any skills to better serve parents and schools; and to make the school a more effective learning community. ${ }^{12}$

Supervisi adalah merupakan suatu proses yang dirancang secara khusus untuk membentuk para guru dan supervisor dalam mempelajari tugas seharihari di sekolah agar dapat menggunakan pengetahuan dan kemampuanya untuk memberikan layanan yang lebih baik pada orang tua, peserta didik, dan sekolah, serta berupaya menjadikan sekolah sebagai lingkungan belajar yang lebih efektif.

Hakekat supervisi adalah suatu proses pembimbingan dari pihak atasan kepada guru dan para personalia sekolah lainnya yang langsung menangani belajar para siswa, memperbaiki situasi belajar mengajar agar para siswa dapat belajar secara efektif dengan prestasi belajar yang semakin meningkat.13

Kegiatan supervisi adalah melakukan pembinaan kepada sekolah pada umumnya dan guru pada khususnya agar kualitas pembelajarannya meningkat. Sebagai dampak kualitas pembelajara, tentu dapat meningkat pula prestasi belajar siswa, dan itu berarti meningkatkan pula kualitas lulusan sekolah itu. Keahlian membuat konsep merupakan kemapuan melihat hubungan satu dengan yang lain. Sebagai supervisor kemampuan membuat konsep meliputi bagaimana masing-masing departemen bisa mencapai target yang ingin dicapai. Keahlian membuat keputusan merupakan kemampuan

11 Syafaruddin, Manajemen Mutu Terpadu dalam Pendidikan, Konsep, Stategi, dan Aplikasi, (Jakarta: PT. Grasindo, 2000), .

12 J. Thomas Sergiovanni, The Principalship: A Reflective Practice Perspective, Second Edition. (Needham Heights: Allyn and Bacon, A Devision of Simon \& Schuster, Inc., 1991), .

${ }^{13}$ Made Pidarta, Manajemen Pendidikan Indonesia, (Jakarta: Rineka Cipta, 2011), . 
menganalisa informasi dan membuat keputusan yang baik. Misalnya, seorang supervisor bisa membuat skala prioritas dan bisa membuat job diskripsi yang tepat. 14

Lebih lanjut, beliau mengatakan bahwa supervisi dapat dibedakan menjadi dua yaitu supervisi akademik dan administrasi. Supervisi akademik adalah supervisi yang menitikberatkan pada masalah akademik yang langsung berada dalam lingkup kegiatan pembelajaran yang dilaklukan oleh guru untuk membantu siswa ketika sedang dalam proses belajar. Supervisi adminstrasi yang menitiberatkan pada pengamatan pada aspek-aspek administrasi yang berfungsi sebagai pendukung terlaksananya pembelajaran.

\section{e. Kepala Sekolah sebagai Leader}

Kepala sekolah bertugas untuk mengatur dan mengurus perjalanan roda organisasi di sekolah. Ia juga diwajibkan untuk membuat program dan melaksanakan kegiatan belajar mengajar dihadapan peserta didik sebagaimana layaknya seorang guru mata pelajaran lainnya. ${ }^{15}$ Kepala sekolah merupakan salah satu komponen pendidikan yang paling berperan dalam meningkatkan kualitas pendidikan. Sebagaimana dikemukakan dalam Pasal 12 ayat 1 PP 28 tahun 1990 bahwa: "Kepala sekolah bertanggungjawab atas penyelenggaraan kegiatan pendidikan, administrasi sekolah, pembinaan tenaga kependidikan lainnya, dan pendayagunaan serta pememliharaan sarana dan prasarana".

Leader posses a vision of what their organization should be like. Know how to motivate and inspire those with whom they work. Understand the major operational levels that can be employed to control or change an organization's course. Are intently sensitive to and continually reflect upon the interaction of external environmental condition and internal organizational dynamics. Understand the fundamental component of strategic thinking that can be used to guide or alter an organization. ${ }^{16}$

Pemimpin mempunyai visi yang harus dicapai organisasi, tahu cara memotivasi dan menginspirasi tim kerja, paham tingkatan kerja yang harus dikerjakan, mengetahui kondisi internal dan eksternal, memahami komponen strategis untuk memandu atau mengubah kondisi organisasi.

Kedudukan kepala sekolah dalam rangka mempercepat pencapaian visi, misi, tujuan dan sasaran yang akan diraih oleh sekolah, diperlukan langkahlangkah yang strategis yang diperlukan dalam menyelesaikan permasalahanpermasalahan yang muncul setiap saat dengan keberagaman permasalahan sekolah yang serba kompleks. Jika semua problem tidak diatasi secepatnya maka akan berdampak dan mampu menyikapi kondisi yang sedang dan akan dialami oleh peserta didik, guru, staf, tata usaha dan tenaga kependidikan lain

\footnotetext{
14 Suharsimi Arikunto, Dasar-Dasar Supervisi, (Jakarta: Rineka Cipta, 2004), .

15 Kemendikbud, Tugas Pokok Kepala Sekolah: UU tentang Tugas dan Tanggung Jawab Kepala Sekolah, Pasal 12 Ayat 1, (Jakarta: Kemendikbud, 1996), .

${ }^{16}$ James W. \& Guthrie, Educational Administration and Policy Affective Leadership for American Education. Second Edition. (Needham Heights: Allyn and Bacon. A Division of Simon \& Schuster;Inc., 1991), .
} 
yang. Kondisi ini akan berpengaruh terhadap cita-cita yang akan dicapai sehingga posisi kepala sekolah sebagai motivator yang artinya adalah "orang yang menyebabkan adanya motivasi pada orang lain untuk melakukan sesuatu" sangat penting. ${ }^{17}$

\section{f. Kepala Sekolah sebagai Innovator}

Sudarwan Danim menyatakan inovasi adalah gagasan, perbuatan atau sesuatu yang baru dalam konteks sosial tertentu dan pada suatu jangka waktu tertentu untuk menjawab masalah yang dihadapi. Sesuatu yang baru, mungkin sudah lama dikenal pada konteks sosial lain atau sesuatu itu sudah lama dikenal tetapi belum dilakukan perubahan. Inovasi dapat juga diartikan sebagai perubahan, tetapi tidak semua perubahan merupakan inovasi. ${ }^{18}$

Kemampuan kepala sekolah sebagai pembuat perubahan memiliki aspekaspek antara lain: kemampuan mencari atau menemukan gagasan baru untuk pembaharuan sekolah dan kemampuan untuk melaksanakan pembaharuan di sekolah. Hal ini mengandung maksud bahwa sebagai seorang pemimpin kepala sekolah harus mencari dan menemukan gagasan baru untuk kemajuan sekolah. Selain itu kepala sekolah harus mempunyai langkah untuk mewujudkan gagasan tersebut dalam bentuk program-program yang harus dilaksanakan. Kepala sekolah hendaknya dituntut untuk selalu melakukan inovasi dalam kebijakan-kebijakannya sehingga sekolah tidak monoton. Kegiatan-kegiatan pembelajaran bisa didesain berbeda dengan inovasi-inovasi yang dilakukannya.

\section{g. Kepala Sekolah sebagai Motivator}

Untuk meningkatkan mutu pendidikan di sekolah, faktor motivasi bagi semua warga sekolah perlu dipupuk dengan baik secara rutin atau berkelanjutan oleh kepala sekolah. Ada tiga ahli yang memberikan sumbangan besar kepada perumusan kebutuhan motivasi itu, yakni Abraham Maslow, Frederick Herzberg dan David McClelland. ${ }^{19}$ :

\section{Teori Motivasi Abraham Maslow}

Menurut teori ini terdapat lima tingkatan kebutuhan dari kebutuhan manusia yang paling rendah sampai kebutuhan yang paling tinggi. Hal ini menimbulkan urutan motivasi dari yang paling rendah samapi motivasi yang apling tinggi. Adapun gambaran urutan hierarki motivasi menurut Maslow terdiri dari: (1) pemenuhan kebutuhan fisiologis, (2) pemenuhan kebutuhan keamanan, (3) pemenuhan kebutuhan sosial, (4) pemenuhan kebutuhan penghargaan, dan (5) pemenuhan kebutuhan aktualisasi diri.

\section{Teori Motivasi Frederick Herzberg}

\footnotetext{
17 Wahjosumidjo, Kepemimpinan Kepala Sekolah; Tinjauan Teoritis dan Permasalahannya, (Jakarta: PT. Grapindo Persada, 2010), .

18 Sudarwan, Inovasi Pendidikan dalam Upaya Peningkatan Profesionalisme Tenaga Kependidikan, (Bandung: PT. Pustaka, 2004), .

${ }^{19}$ Moekijat, Kepemimpinan di Sekolah, (Bandung: PT. Remaja Rosdakarya, 1980), .
} 
Herzberg mengungkapakan tentang teori dua faktor yakni faktor intrinsik (motivasi) dan faktor ekstrinsik (kesehatan). Teori motivasi kesehatan dari Herzberg merupakan salah satu teori yang paling berhasil untuk menggambarkan mengenai motivasi pada pekerjaan. Untuk tujuan pengembangan manajemen, sumbangan Herzberg yang besar adalah kesimpulan yang ia tarik mengenai perencanaan pekerjaan.

Adapun gambaran lengkap tentang teori ini adalah sebagai berikut:

Teori Motivasi Frederick Herzberg

\begin{tabular}{|l|l|}
\hline \multicolumn{1}{|c|}{ Faktor Motivasi (Intrinsik) } & \multicolumn{1}{c|}{ Faktor Kesehatan (Ekstrinsik) } \\
\hline 1. Prestasi & 1. Supervisi \\
2. Penghargaan & 2. Kondisi kerja \\
3. Pekerjaan itu sendiri & 3. Hubungan interpersonal \\
4. Tanggungjawab & 4. Bayaran dan keamanan \\
5. Pertumbuhan/perkembangan & 5. Kebijakan perusahaan \\
\hline
\end{tabular}

\section{Teori Motivasi McClelland}

McClelland mengetengahkan teori motivasi yang berhubungan erat dengan teori belajar. Teori David McClelland menitik beratkan pada kebutuhan akan prestasi (need of achievement) dalam kebutuhan motivasi mereka, kebutuhan akan afiliasi (need of affiliation), dan kebutuhan akan kekuasaan (need of power). Hubungan antara motivasi dan prestasi sangat penting, karena orang yang berhasil dalam bekerja di perusahaan adalah orang-orang yang menyelesaikan tugas dengan penuh motivasi.

Kepala sekolah sebagai pemimpin harus mampu; mendorong timbulnya kemauan yang kuat denagn penuh semangat dan percaya diri para guru, staf dan siswa dalam melaksanakan tugasnya masing-masing. Memberikan bimbingan dan mengarahkan guru, staf, dan siswa serta memberikan dorongan memacu dan berdiri di depan demi kemajuan dan memberikan inspirasi sekolah dalam mencapai tujuan. ${ }^{20}$

Berdasarkan uraian tersebut, maka kepala sekolah yang ingin menggerakkan para guru harus menghindarkan dari sifat dan perbuatan yang memaksa atau bertindak keras terhadap para guru, staf, dan siswa. Kepala sekolah harus mampu melakukan perbuatan yang mampu mendorong kemauan untuk bekerja denagan penuh semangat dan percaya diri terhadap para guru, staf, dan siswa dengan cara meyakinkan (persuade) berusaha agar para guru, staf, dan siswa percaya bahwa apa yang dilakuakan adalah benar, membujuk (induce) berusaha meyakinkan para guru, staf, dan siswa bahwa apa yang mereka kerjakan adala benar.

\section{Peran Kepala Sekolah dalam Peningkatan Mutu Pendidikan}

20 Wahjosumidjo, Kepemimpinan Kepala Sekolah; Tinjauan Teoritis dan Permasalahannya, (Jakarta: PT Grapindo Persada, 2010), . 
Peran kepala sekolah dalam proses peningkatan mutu pendidikan sangatlah penting. Peran tersebut meliputi:

\section{a. Perumusan Visi, Misi, Tujuan dan Sasaran}

Kepala sekolah yang bertanggung jawab berusaha mengetahui visi sekolahnya. Jika belum ada, mereka akan berusaha merumuskannya dengan melibatkan semua pihak yang berkepentingan. Visi itu kemudian disosialisasikan sehingga menjadi cita-cita bersama. Selanjutnya ia akan berusaha secara konsisten untuk terus berupaya menggalang komitmen untuk mewujudkan visi itu. Ia tidak akan berdiam diri membiarkan visi itu menjadi rumusan indah yang menghiasi dinding kantornya. ${ }^{21}$

Penjabaran dari teori tersebut adalah a) Visi dan misi disusun bersamasama dengan pihak-pihak yang berkepentingan yakni staf, keluarga murid, dan anggota masyarakat memahami visi dan misi sekolah. b) Pihak-pihak berkepentingan yakin bahwa inti visi sekolah dipakai sebagai pedoman bagi semua yang terlibat dalam urusan sekolah. c) Kontribusi anggota komunitas sekolah dalam pewujudan visi itu dihargai. Pihak-pihak yang berkepentingan menerima informasi tentang kemajuan upaya pencapaian visi sekolah. Komunitas sekolah terlibat aktif dalam upaya peningkatan sekolah. d) Program, rencana, dan kegiatan sekolah telah tersusun berdasarkan visi sekolah. Rencana berdasarkan tujuan dan strategi yang jelas dilaksanakan. e) Data penilaian pembelajaran peserta didik digunakan untuk menyusun visi dan tujuan sekolah. Data demografik murid dan keluarganya digunakan untuk menyusun misi dan tujuan sekolah. f) Pengadaan sumber daya yang diperlukan untuk mendukung implementasi misi dan tujuan sekolah telah diupayakan. g) Sumber daya yang ada untuk mendukung visi dan tujuan telah digunakan dengan efektif dan efisien. h) Visi, misi, dan rencana telah dipantau, dievaluasi, dan direvisi secara teratur.

Pendapat lain adalah perumusan misi dapat disusun berdasarkan visi yang telah ditetapkan bersama. Misi yang dirumuskan harus dapat menjelaskan semua tujuan suatu organisasi. Misi biasanya dituangkan dalam kalimat pendek sehingga mudah diingat dan komunikatif. Misi yang demikian diharapkan dapat memberikan pedoman tehadap apa yang dilakukan oleh orang-orang dalam suatu organisasi.

\section{b. Pengambilan Keputusan}

Keputusan dalam suatu organisasi, termasuk sekolah, merupakan dasar bagi berfungsinya suatu organisasi. Kepala sekolah merupakan aktor utama dalam pengambilan keputusan. Kepala sekolah mempunyai direction untuk menentukan misi sekolah, program pendidikan, proses belajar mengajar, serta recruitment system. Meskipun demikian, discreation ini tidak berarti bahwa

21 Agus Dharma, "Dicari Kepala Sekolah yang Kompeten: Standard Kompetensi Kepala Sekolah," http://artikel.us/adharma.html, diakses pada tanggal 11 Maret 2012. 
kepala sekolah secara otoriter dapat mengambil keputusan berdasarkan pertimbangan subyektif kepala sekolah.22

Proses pengambilan keputusan partisipatif merupakan salah satu inti dari proses peningkatan mutu sekolah. Esensi proses pengambilan keputusan partisipatif adalah untuk mencari wilayah kesamaan antara kelompokkelompok kepentingan yang terkait dengan sekolah (stakeholders). Wilayah kesamaan inilah yang menjadi modal dasar untuk menumbuhkan rasa memiliki bagi semua kelompok kepentingan yang terkait dengan sekolah. Ini dapat dilakukan secara efektif melalui pelibatan semua kelompok kepentingan dalam proses pengambilan keputusan.

\section{c. Analisis SWOT}

SWOT is an acronym for the internal Strengths and Weaknesses of a firm and the environmental Opprotunities and Threats facing that firm. SWOT analysis is an easy technique through which managers create a quick overview of a company's strategic situation. ${ }^{23}$

Analisis SWOT (Strength, Weakness, Opportunity, and Threat) merupakan alat perencanaan yang strategis yang lazim digunakan pada perusahaan, termasuk di dalamnya bisa juga digunakan untuk pendidikan. Analisis ini merupakan cara yang paling efektif untuk mengalokasikan potensi suatu institusi baik secara internal (dalam perusahaan) maupun secara eksternal (lingkungan perusahaan). Adapun penjabaran tentang SWOT adalah sebagai berikut:

(1) Strengths, merupakan sebuah sumber daya, ilmu atau kelebihan lain yang berhubungan dengan pesaing dan kebutuhan pemasaran sebuah perusahaan untuk memberikan layanan. Kekuatan bisa berupa sumber daya finansial, image terhadap perusahaan, dan hubunganya dengan pembeli.

(2) Weaknesses, adalah keterbatasan sumber daya, ilmu atau kemampuan perusahaan yang berdampak pada efektivitas perusahaan seperti: fasilitas, sumber daya finansial, kemampuan manajemen, pemasaran, dan image yang bisa menimbulkan kelemahan.

(3) Opportunities, merupakan situasi pokok dalam lingkungan perusahaan seperti: segmen pasar, perkembangan teknologi dan persaingan, dan peningkatan hubungan pembeli dan supplier.

(4) Threats, merupakan ancaman terhadap posisi perusahaan seperti masuknya pesaing baru, lambatnya perkembanagn pasar, perubahan teknologi, dan adanya peraturan perundangan baru.

\section{d. Penyusunan Program Peningkatan Mutu}

Berdasarkan langkah-langkah pemecahan persoalan yang telah diputuskan, kepala sekolah bersama-sama dengan semua unsur yang terkait

22 Wahjosumidjo, Kepemimpinan Kepala Sekolah; Tinjauan Teoritis dan Permasalahannya, (Jakarta: PT. Grapindo Persada, 2010), .

23 Pearce A. J. \& Robinson C, Strategic Management: Formulation, Implementation, and Control, (New York: Times Mirror Higher Educational Group, Inc., 1997), . 
membuat perencanaan untuk jangka pendek, menengah, dan jangka panjang. Rencana ini harus menjelaskan secara detail tentang aspek-aspek mutu yang dinginkan, kegiatan yang harus dilaksanakan, dan berapa biaya yang diperlukan untuk merealisasikan kegiatan tersebut. Hal ini dilakukan untuk memudahkan sekolah dalam menjelaskan dan memperoleh dukungan dari pemerintah maupun masyarakat, baik secara moral maupun finansial untuk melaksanakan rencana peningkatan mutu pendidikan.

\section{e. Keterbukaan}

Hal pokok yang perlu diperhatikan oleh kepala sekolah dalam penyusunan rencana atau program adalah keterbukaan kepada semua pihak yang menjadi stakeholder pendidikan ${ }^{24}$. Dengan cara demikian akan diperoleh kejelasan, berapa kemampuan sekolah dan pemerintah untuk menanggung biaya suatu rencana dan berapa sisanya yang harus ditanggung oleh orang tua peserta didik dan masyarakat sekitar.

Konsep tersebut jelas bahwa dengan sistem keterbukaan siapa saja bias mengakses program dan rencana sekolah. Hal tersebut akan memperlancar program yang ada karena stakeholder bisa melakukan evaluasi terhadap rencana dan program yang ada sehingga control tetap tercapai. Hal ini juga bias mengantisipasi masalah-masalh yang timbul karena semua pihak terutama sakeholder mengetahui dengan jelas program sekolah.

\section{f. Partisipasi Warga Sekolah dan Masyarakat}

Ada dua hal penting yang perlu dilakukan oleh kepala sekolah yaitu hubungan sekolah dengan masyarakat dan penggunaan sumber daya eksternal. Hubungan sekolah dengan masyarakat dibangun dalam rangka proses peningkatan mutu, seorang kepala sekolah memerlukan dukungan banyak sumber-sumber daya dari masyarakat dimana sekolah itu berada. Menurut Wahjosumidjo agar dukungan yang diperoleh dapat didayagunakan dengan tepat, maka diharapkan: (a) kepala sekolah mampu menunjukkan rasionalitas usaha perbaikan tercapainya tujuan organisasi dan harapan para individu; (b) kepala sekolah harus menaruh perhatian terhadap sejumlah bentuk dan arus informasi; (c) kepala sekolah mampu mempergunakan kepemimpinannya dan membangun saluran komunikasi responsif, baik dilingkungan organisasi sekolah maupun masyarakat yang lebih luas; (d) kepala sekolah dapat mengubah organisasi yang birokratis dan mekanistik menjadi organisasi yang dinamis dan organik.

Selain penggunaan sumber daya eksternal, seorang kepala sekolah bertanggung jawab membangun hubungan kerjasama yang tepat antara sebuah sekolah dengan aparat-aparat pembaharuan pendidikan seperti perguruan tinggi, pusat-pusat riset dan pengembangan, dan organisasiorganisasi yang bertanggung jawab dalam pengelolaan produksi dan pengetahuan.

\section{g. Kemandirian dan Akuntabilitas}

24 Wahjosumidjo, Kepemimpinan Kepala Sekolah; Tinjauan Teoritis dan Permasalahannya, (Jakarta: PT. Grapindo Persada, 2010), . 
Hal penting dalam meningkatkan mutu pendidikan seorang kepala sekolah harus menerapkan jiwa mandiri pada staf yang dipimpinnya.

Principals prepare budgets and reports on various subjects, including finance attendance, and oversee the requisition and allocation of supplies. As school budget become tighter, many principals have become more involved in public relations and fundraising to secure financial support for their schools from local businesses and the community. 25

Kepala sekolah harus menyiapkan anggaran dan laporannya dalam berbagai bidang termasuk sumber dana dan penggunaannya. Karena dana sekolah semakin tinggi, maka kepala sekolah harus melibatkan diri dalam hubugan publik untuk mendapatkan dana baik dari masyarakat atau usahausaha lokal.

Program kerja yang dibuat dan dilaksanakan oleh sekolah harus disosialisikan kepada semua warga sekolah dan masyarakat yang terkait. Sekolah membelanjakan dan menggunakan dana harus diketahui oleh warga sekolah dan masyarakat. Pertanggung jawaban dana mulai dari perencanaan, penggunaan sampai dengan akhir program kepada warga sekolah dan masyarakat atau BP3. Pertanggung jawaban dapat dilakukan melalui rapat, pertemuan atau laporan.

\section{h. Perubahan Menuju Sadar Mutu}

Pelaksanaan menuju sadar mutu pendidikan, kepala sekolah perlu melakukan perubahan budaya (Change Culture). untuk itu perlu perubahan sikap, perilaku staf dan cara mengelola suatu institusi sekolah yang pada gilirannnya ditandai dengan pemahaman warga sekolah dalam memberikan atau menghasilkan sesuatu yang bermutu. ${ }^{26}$

Lebih lanjut, Nahavandi menegaskan bahwa ada dua hal pokok yang perlu diperhatikan staf untuk dapat memberikan suatu hasil pekerjaan yang bermutu. Pertama, staf memerlukan lingkungan yang cocok untuk bekerja. Kedua, staff memerlukan dorongan dan kesadaran akan keberhasilan dan prestasi. Hal ini perlu diperhatikan dan diimplementasikan oleh kepala sekolah sebagai agen perubahan (Change Agent) sekaligus sebagai fasilitator perubahan.

\section{Penutup}

Peran kepala sekolah sebagai sebagai educator, manager, administrator, supervisor, leader, innovator, atau motivator sangat penting diketahui dan diterapkan oleh kepala sekolah. Sebagai pendidik, ia bisa menyelenggarakan program pembelajaran dengan menggunakan kurikulum yang difokuskan pada tiga bidang yaitu bidang keagamaan, bidang akademis, dan bidang kreatifitas. Kepala sekolah sebagai pemimpin pendidikan Islam juga harus mampu menciptakan

${ }^{25}$ Kathleen Cushman, "The Essential School Principal: A Changing Role In A Changing School," http://www.essentialschool.org/cs/resource/viw/ces res/102, diakses pada tanggal 12 Maret 2012.

${ }^{26}$ Afsaneh Nahavandi, The Art and Science of Leadership, (Upper Saddle River: Prentice Hall, Inc., 1997), . 
lingkungan sekolah yang representatif dengan cara membiasakan kedisiplinan, menciptakan suasana kekeluargaan, meningkatkan kebersihan lingkungan sekolah dan menerapkan hadiah dan hukuman. Hal tersebut jika diterapkan akan terjadi dinamisasi lingkungan kerja dengan suasana yang nyaman, terkendali, semangat untuk mencapai tujuan. Sebagai dampaknya akan tercipta lingkungan sekolah yang kondusif untuk belajar sehingga menghasilkan lulusan yang berkualitas dan siap berkompetisi di dunia global.

Sebaliknya, jika lembaga pendidikan Islam tidak menerapkan konsep-konsep kepemimpinan tersebut akan menerima konsekwensi mundurnya lembaga pendidikan Islam tersebut. Sebagai dampaknya, maka generasi-generasi Islam sebagai penerus estafet kepemimpinan di masa datang akan mengalami kemunduran dalam hal pendidikan. Oleh karena itu, kualitas seorang pemimpin dalam lembaga pendidikan Islam sudah merupakan keharusan dan tidak bisa ditawar-tawar lagi karena kebutuhan yang semakin mendesak. Sudah saatnya lembaga pendidikan Islam muncul menunjukkan jati dirinya dengan kualitas terbaik karena dipimpin oleh seorang kepala sekolah yang berkualitas. 


\section{DAFTAR PUSTAKA}

Komariah, Aan \& Cepi Triatna, 2006, University Leadership, Menuju Sekolah Efektif, Jakarta: PT. Bumi Aksara.

Sudrajat, Akhmad, "Kepemimpinan Pendidikan," (http://.wordpress.com/ kompetensi-guru-dan-peran-kepala-sekolah-2/), diakses pada tanggal 20 Mei 2014.

Dharma, Agus, 2003, "Dicari Kepala Sekolah yang Kompeten: Standard Kompetensi Kepala Sekolah," http://artikel.us/adharma.html, diakses pada tanggal 11 Maret 2012.

Bush, T., \& Coleman M., 2000, Leadership and Strategic Management in Education, London: Paul Chapman Publishing Ltd.

Cushman, Kathleen, "The Essential School Principal: A Changing Role In A Changing School," http://www.essentialschool.org/cs/resource/viw/ces res/102, diakses pada tanggal 12 Maret 2012.

James W., \& Guthrie, 1991, Educational Administration and Policy Affective Leadership For American Education, Second Edition, Needham Heights: Allyn and Bacon. A Division of Simon \& Schuster;Inc.

Kemendikbud, 1996, Tugas Pokok Kepala Sekolah: UU tentang Tugas dan Tanggung Jawab Kepala Sekolah, Pasal 12 Ayat 1, Jakarta: Kemendikbud.

Lunenburg, F. C., 2004, Educational Administration, Belswart: Wordsworth.

Pidarta, Made, 2011, Manajemen Pendidikan Indonesia, Jakarta: Rineka Cipta.

Moekijat, 1980, Kepemimpinan di Sekolah, Bandung: PT. Remaja Rosdakarya.

Syaifuddin, Muh., “Sumbangan Gaya Kepemimpinan Partisipatif Kepala Sekolah, Pembinaan oleh Kepala Sekolah, dan Iklim Organisasi Sekolah pada Kinerja Guru," Tesis, tidak diterbitkan, 2002.

Nahavandi, Afsaneh, 1997, The ARt and Science of Leadership, Upper Saddle River: Prentice Hall, Inc.

Pearce A. J., \& Robinson C., 1997, Strategic Management: Formulation, Implementation, and Control, New York: Times Mirror Higher Educational Group, Inc. 
Jasaah, Saeeda, "Re-thinking Educational Leadership: Exploring The Impact of Cultural and Belief Systems," (http://www.tandfonline.com/page/termsandconditions. dx.doi.org/10.1080/13603120903244879), diakses tahun 2010.

Syafaruddin, 2002, Manajemen Mutu Terpadu dalam Pendidikan, Konsep, Strategi, dan Aplikasi, Jakarta: PT. Grasindo.

Sergiovanni, J. Thomas, 1991, The Principalship: A Reflective Practice Perspective, Second Edition, Needham Heights: Allyn and Bacon, A Devision of Simon \& Schuster, Inc.

Danim, Sudarwan, 2004, Inovasi Pendidikan dalam Upaya Peningkatan Profesionalisme Tenaga Kependidikan, Bandung: PT. Pustaka.

Arikunto, Suharsimi, 2004, Dasar-Dasar Supervisi, Jakarta: Rineka Cipta.

Wahjosumidjo, 2010, Kepemimpinan Kepala Sekolah; Tinjauan Teoritis dan Permasalahannya, Jakarta: PT. Grapindo Persada.

Winardi, 2000, Manajemen Sekolah Dan Kepemimpinan Mandiri Kepala Sekolah. Edisi 2, Bandung: Sarana Punca Karya Nusa. 